УДК 655.5:005.412(091)

\author{
Купріна H.M. \\ кандидат економічних наук, доцент \\ кафредра обліку та аудиту \\ E-mail:k.natali@ukr.net \\ Рудюк I. \\ Студент 4 курсу фракультету економіки, бізнесу і контролю \\ Одеська національна академія харчових технологій \\ вул. Канатна, 112, м. Одеса, Україна, 65039 \\ E-mail: ruduk2012@gmail.com
}

\title{
РОЗВИТОК УПРАВЛІНСЬКОГО ОБЛІКУ: ІСТОРИЧНИЙ ТА ПРАКТИЧНИЙ АСПЕКТ
}

\begin{abstract}
В статті проведено аналіз сучасних підходів щодо визначення сутності категорій «управлінський облік», «стратегічних управлінський облік», підходів в наукових працях іноземних і українських вчених щодо етапів розвитку управлінського обліку в історичному та практичному аспекті та їх узагальнення: для структурування розвитку управлінського обліку за окремими етапами в історичному аспекті. Проведене дослідження етапів розвитку управлінського обліку дозволило обґрунтувати виділення стратегічного управлінського обліку, як сучасного виду обліку, що обумовлено впливом факторів зовнішнього середовища над внутрішніми на функціонування суб'єктів господарювання, та сприяє забезпеченню їх ефективної діяльності та конкурентоспроможності.

Ключові слова: управлінський облік, стратегічних управлінський облік, етапи розвитку, підприємство, зовнішні фактори, конкурентоспроможність.
\end{abstract}

This work is licensed under a Creative Commons Attribution 4.0 International License http://creativecommons.org/licenses/by/4.0/

Постановка проблеми та її зв'язок з важливими науковими та практичними завданнями. Сучасний стан економіки України та активний вплив глобалізаційних процесів на іiі розвиток, призводить до необхідності пошуку інструментів забезпечення ефективності функціонування та конкурентоспроможності всіх іiі суб'єктів, тому важлива роль у розв'язанні цієї задачі належить саме сучасному управлінському обліку, як дієвому інструменті ефективного управління. Система управлінського обліку охоплює сукупність прийомів, методів, інструментів, систем, стратегій які обираються відповідно до поставлених завдань, які формувались за великій історичний період та виникнення яких було обумовлено розвитком підприємств, зовнішньої та внутрішньої середи їх функціонування [1]. В сучасних наукових публікаціях проводиться дискусія щодо етапів розвитку українського обліку в Україні та іноземних країнах, існування самого управлінського обліку в Україні, як самостійного виду бухгалтерського обліку, визначення сутності економічної категорії «управлінський облік» та сучасних видів такого обліку, що потребує додаткових досліджень.

Аналіз останніх публікацій 3 проблеми. Дослідження вітчизняними та зарубіжними вченими стану, розвитку, проблем та аспектів застосування й розвитку управлінського обліку відображені у наукових, практичних та методичних працях, таких вчених як, І.В.Аверчева, А. Апчера, П.Й. Атамаса, М.В. Болдуєва, М.А. Вахрушіна, Д.А. Волошина, В.П. Галенко, Р. Гаррісона, С.Ф. Голова, Ш. Датара, Т.П. Карпової, О.В. Карпенко, О.М. Костенко, В.Е. Керімова, О.В. Ковальової, Т.А. Кольцової, Н.П. Кондракової, В.С. Леня, О.Г. Лищенко, М.З. Матвійчук, Б. Нідлза, Л.В. Нападовської, М.С. Пушкар, В.С. Рудницького, Т.Скоуна, В.В. Сопка, Ч. Хорнгрена, Дж. Фостера, М.Г. Чумаченка, А.Д. Шеремета, Л.Ю. Шевців, М.Т. Щирби та ін. [1], але й не втрачають своєї актуальності у теперішній час та потребують додаткових досліджень.

Формування цілей дослідження. Аналіз підходів в наукових працях іноземних і українських вчених та практичних публікаціях професійних організацій щодо етапів розвитку управлінського обліку в історичному та практичному аспекті показав, що $є$ різниця в історичних аспектах структурування етапів розвитку управлінського обліку та й їх змісту, що потребує узагальнення етапів та обгрунтування нового їх структурування та нових досліджень, а також обгрунтування виділення стратегічного управлінського обліку на сучасному етапі розвитку управлінського обліку - сучасного виду бухгалтерського обліку, що обумовлено впливом факторів зовнішнього середовища над внутрішніми на функціонування суб'єктів господарювання.

Виклад основних результатів та їх обгрунтування. Попередні дослідження показали, що 
зміни в зовнішньому середовищі суттєво впливають на функціонування підприємства, забезпечення ефективної діяльності та конкурентоспроможності, тому його вже не можливо називати внутрігосподарським, а саме - це система збору, ідентифікації, накопичення, вимірювання, обробки, аналізу, підготовки та передачі інформації про діяльність підприємства для внутрішніх користувачів для прийняття управлінських рішень у процесі стратегічного та поточного управління підприємством [2], що потребує подальших досліджень для ефективного управління та забезпечення конкурентоспроможності та ефективності діяльності вітчизняних підприємств.

Постановка проблеми та їі зв'язок $з$ важливими науковими та практичними завданнями. Як показало дослідження, перша згадка про виникнення управлінського обліку датується 1855 р. в США та відноситься до системи обліку, що застосовувалась на фабриці «ЛіманМіллс» і була спроектована, виходячи з цілей більш ефективного моніторингу виробничого процесу [3]. Так, у США формування управлінського обліку розпочинається 3 перших спроб уніфікації облікових процедур, висування вимог про необхідність побудови теорії обліку, розвитку наукової інтерпретації, постулатів і принципів, формування методологічних підходів до дослідження бухгалтерського обліку.

Дослідження показали [4], що у 1972 р. проголошується «облікової революцією» це означає початок подальшого розвитку двох систем - фінансового та управлінського обліку та проводяться самостійні дослідження в області кожного з них, здійснюється сертифікація за напрямом «Управлінський облік i внутрішнє аудіювання» (Industrial Accounting) з видачею сертифікату з управлінського обліку - Certified Management Accountant (CMA), що проводиться Інститутом професійних бухгалтерів з управлінського обліку (The Institute of Management Accounting). 3 початку 1990-х рр. отримують розробку нові методи управлінського обліку: загальна система управління витратами - Total Cost Management (TCM), облік витрат за видами діяльності - Activity Based Costing (ABC), або диференційований облік, калькулювання за операціями, система збалансованих показників The Balanced Scorecard (BSC). Аналогічна модель управлінського обліку розвивається і в ВеликобритаHiï.
У Франції аналогом управлінського обліку виступає маржинальна бухгалтерія, яка розвивається в контексті переважно економічного спрямування, поступово витісняе юридичний напрямок, під впливом англо-американської облікової моделі (з середини 1950-х рр.) [4].

У Федеративній Республіці Німеччині (у 1949-1990 рр.) аналогом управлінського обліку є виробничий облік витрат, що розглядається підсистемою бухгалтерського обліку, включеного в загальну організацію підприємства в зв'язку з важливістю внутрішньовиробничих процесів основний зміст яких становить концепція доданої вартості, а облік витрат акумулює, документує, обробляє і аналізує (інтерпретує) комплекс взаємопов'язаних виробничих операцій. Така організація виробничого обліку витрат робить його схожим 3 французької, але відмінною від англо-американської моделі управлінського обліку, хоча і припускає використання притаманних управлінському обліку методів, які застосовуються також в контролінгу (системі управління прибутком, в якій управлінський облік розглядається інформаційним ланкою) [5].

Систематизація світового внеску у формування концепції управлінського обліку дозволяє розробити періодизацію його розвитку. В результаті можна виділити два великих історичних періоду, в яких формуються передумови виникнення управлінського обліку, відбувається його становлення і розвиток.

У періоді становлення і розвитку управлінського обліку, який пов'язаний з розробкою методології управлінського обліку та його розвитком, можна виділити три етапи [6]:

1. 1920-1950 pp. - розробка специфічних прийомів, методів управлінського обліку, формування його цілей.

2. 1950-1990 pp. - розвиток традиційних систем управлінського обліку (стандарткост, директкостинг, калькулювання повної собівартості, розподіл витрат, оцінка беззбитковості і т.п.).

3. 1990- по даний час - розвиток інноваційних систем управлінського обліку (калькуляційної системи АВС, «точно в строк», стратегічного управлінського обліку тощо).

На думку Добровського В.М., Гнилицької Л.В., Коршикової Р.С. [7], всю історію розвитку управлінського обліку можна звести до чотирьох етапів (табл. 1).

Таблиця 1

Етапи розвитку управлінського обліку, які сформовані В.М.Добровським, Л.В.Гнилицької, P.С. Коршикової*

\begin{tabular}{|l|l|}
\hline \multicolumn{1}{|c|}{ Період, етап } & \multicolumn{1}{c|}{ Сутність } \\
\hline $\mathbf{1}$ етап - середина ХІХ ст. & Облік починають розглядати як функцію управління. \\
\hline $\begin{array}{l}\mathbf{2} \text { етап - Початок ХХ ст. - } \\
\text { середина 50-х років ХХ ст. }\end{array}$ & $\begin{array}{l}\text { Становлення капіталістичної системи господарювання, відбувається виділення } \\
\text { управлінського обліку як окремої системи і паралельне функціонування двох } \\
\text { бухгалтерій (фінансової та управлінської). }\end{array}$ \\
\hline $\mathbf{3}$ етап - 50-80-ті роки ХХ ст. & $\begin{array}{l}\text { Розвиток транснаціональних корпорацій, відбувається впровадження директко- } \\
\text { втиу. Управлінський обік формується як самостійна система, перетворюється } \\
\text { в «учасника» і «виконавця» управлінської політики підприємства. }\end{array}$ \\
\hline $\mathbf{4}$ етап - з 80-х років XX ст. & $\begin{array}{l}\text { Глобалізація економіки й інтеграція національних економік країн у єдиний сві- } \\
\text { товий ринок, управлінський облік набуває стратегічного характеру. }\end{array}$ \\
\hline
\end{tabular}

* Сформовано авторами на підставі [7] 
Упровадження нової системи управлінського обліку (системи АВС) дало можливість його переорієнтації від управління суто виробничими процесами до управління іншими функціями бізнесу.
Міжнародна федерація бухгалтерів (МФБ, $1998)$ визначила чотири етапи, протягом яких еволюціонував управлінський облік (табл. 2).

Таблиця 2

Етапи розвитку управлінського обліку, які сформовані міжнародною федерацісю бухгалтерів (МФБ, 1998)*

\begin{tabular}{|c|l|}
\hline \multicolumn{1}{|c|}{ Період, етап } & \multicolumn{1}{|c|}{ Сутність } \\
\hline $\mathbf{1}$ етап - до 1950 року & $\begin{array}{l}\text { Основна увага була приділена визначенню вартості виробництва та здійсненню } \\
\text { фінансового контролю, через використання бюджетування й технологій обліку } \\
\text { витрат. }\end{array}$ \\
\hline $\mathbf{2}$ етап - до 1965 року & $\begin{array}{l}\text { Надання інформації для планування, управління та контролю, за рахунок викорис- } \\
\text { тання таких технологій, як аналіз прийняття рішень і врахування відповідальності. }\end{array}$ \\
\hline $\mathbf{3}$ етап - до 1985 року & $\begin{array}{l}\text { Увагу було зосереджено на скороченні відходів ресурсів, які використовуються в } \\
\text { бізнес-процесах, за допомогою використання процесу аналізу і технологій управ- } \\
\text { ління витратами. }\end{array}$ \\
\hline $\mathbf{4}$ етап - до 1995 року & $\begin{array}{l}\text { Увагу було зосереджено на генерації або створенні вартості завдяки ефективному } \\
\text { використанню ресурсів, шляхом використання технологій, базованих на дослі- } \\
\text { дженні значення акціонерної вартості і організаційних інновацій. }\end{array}$ \\
\hline
\end{tabular}

* Сформовано авторами на підставі [8]

На думку П. Й. Атамаса у процесі формуван- чотири етапи (табл. 3). ня і розвитку управлінського обліку можна виділити

Таблиця 3

Етапи розвитку управлінського обліку, які сформовані П. Й. Атамасом*

\begin{tabular}{|c|c|}
\hline Період, етап & Сутність \\
\hline $\begin{array}{l}1 \text { етап - кінець XIX - } \\
\text { початок XX ст. }\end{array}$ & $\begin{array}{l}\text { Період характеризується збільшенням кількості великих підприємств, що в свою } \\
\text { чергу сприяло зростанню потреби в нових методах обліку і управління. Почали } \\
\text { визначатися такі показники, як вартість часу обробки сировини, собівартість оди- } \\
\text { ниці продукції, витрати на одного робітника. }\end{array}$ \\
\hline $\begin{array}{l}2 \text { етап - перша половина } \\
\text { ХХ ст. }\end{array}$ & $\begin{array}{l}\text { В періоді характерним є загострення конкуренції, ускладнення технології й органі- } \\
\text { зації виробництва. Впроваджено систему калькулювання стандартних витрат і } \\
\text { оперативного аналізу відхилень. }\end{array}$ \\
\hline $\begin{array}{l}3 \text { етап - 50-ті - початок } \\
70 \text {-х рр. XX ст. }\end{array}$ & $\begin{array}{l}\text { Подальший розвиток ідей управлінського обліку. Розробка Спенсером А. Такером } \\
\text { методу «тариф - година - машина», що посилювало контроль за кожним техноло- } \\
\text { гічним процесом в межах виробничого центру відповідальності. }\end{array}$ \\
\hline $\begin{array}{l}4 \text { етап - Середина 70-х } \\
\text { рр. - кінець ХХ ст. }\end{array}$ & $\begin{array}{l}\text { Характерними рисами періоду є автоматизація виробництва, комп’ютерні інфор- } \\
\text { маційні технології, глобальна конкуренція. Управлінський облік стає складовою } \\
\text { частиною процесу стратегічного управління. }\end{array}$ \\
\hline
\end{tabular}

* Сформовано авторами на підставі [9]

Дослідження сучасних публікаціях вчених, присвячених розвитку управлінського обліку в Україні показало, що існує полеміка авторів щодо його існування та напрямів розвитку. Так, дослідження О. Королович показало [10], що більшість вченихекономістів погоджуються, що управлінський облік $\epsilon$ системою збирання і узагальнення інформації у вигляді, необхідному для забезпечення інформаційних потреб управління. Однак не варто говорити про виокремлення його в окрему інформаційну систему: управлінський облік повинен бути однією із підсистем єдиної інформаційної системи управління підприємством.

Аналіз наукової літератури О. Королович дозволів виявити різноманітність поглядів щодо ви- значення управлінського обліку,його зв'язку з іншими елементами облікової системи,а саме [10]: «управлінський облік як окремий вид обліку не існує», оскільки «така міфічна система ... нежиттєздатна в основі,концептуально помилкова»; «управлінський облік $є$ первинним, оскільки він грунтується на первинних документах».

О.В.Акольська та О.Б. Білоцерківський у своєму дослідження зазначають [11], що «деякі автори, зокрема Ф.Ф. Бутинець ..., поставили під сумнів існування в Україні управлінського обліку. Порівнявши визначення цього виду обліку, яке подається у ряді опублікованих робіт цей автор перш за все визначає, що у світі існує кілька близьких за змістом понять, а саме: у Франції - маржинальний облік, у 
Німеччині - обчислення витрат і результатів і лише в англомовних країнах (США, Англії та Канаді) управлінський облік. Одночасно було звернуто увагу на те, що в це поняття входить не тільки формування та контроль витрат на протязі звітного періоду, а й обгрунтовується необхідність прийняття управлінських рішень на перспективу».

На відміну від них, Т.А Крушельницька та Г. Є. Павлова вважають [12] що управлінський облік $€$ інструментом управління діяльністю підприємства, об'єднуючи практично всі функції управління: облік, планування, координацію, контроль, аналіз, прийняття рішень.

За результатами дослідження структури управлінського обліку, його основних функцій, порядку застосування і функціонування автори дійшли висновку, що управлінський облік є однією зі складових системи управління. На відміну від вище перелічених науковців, більшість авторів визнає не тільки існування управлінського обліку, але й надають визначення сутності даної категорії та її складових.

На думку О. М. Костенко [13] управлінський облік - це інструмент управління діяльністю підприємства, що сприяє інтеграції функцій управління та стадій їх реалізації. Управлінський облік суттєво відрізняється від традиційного бухгалтерського обліку, орієнтованого на складання фінансової звітності.

Л. В. Нападовська зазначає [14], що метою управлінського обліку є допомога внутрішнім користувачам приймати більш обгрунтовані рішення, забезпечення менеджерів інформацією, яка надає можливості примножити капітал іiі власникам, а працівникам підприємства - збільшити цінність їх матеріального та духовного добробуту, підвищення ефективності управління, а отже - ефективності планування, нормування, контролю та прийняття управлінських рішень.

В умовах ринкової економіки управлінський облік змінює своє значення та переорієнтується 3 внутрішніх факторів впливу на зовнішні. Сучасний управлінський облік, використовує як зовнішню так i внутрішню інформацію, а також принципи бюджетування, здійснює аналіз діяльності підприємства з урахуванням як поточних, так і довгострокових цілей. Він все більше перетворюється на стратегічний управлінський облік, основою якого є стратегічне управління витратами [7]. Стратегічне управління витратами передбачає використання даних про витрати на розробку і визначення кращих стратегій, що забезпечать стійку конкурентну перевагу. Зокрема Дж. Шанк і В. Говіндараджен підкреслювали, що одним 3 найважливіших досягнень був перехід від обліку витрат до їх управлінського аналізу. Але основним завданням на майбутнє є перехід від управлінського аналізу до стратегічного управління витратами, яка виникла у зв'язку зі зростанням ролі стратегії за останні 20 років.

О.Г. Лищенко та Ю.А. Герасименко стверджують [15] що,за розвиток сучасного управління підприємством відповідає стратегічний управлінсь- кий облік, який потребує зміни облікових підходів 3 метою створення надійного інформаційного забезпечення. Дослідження показало, що словосполучення «стратегічний облік», «стратегічний управлінський облік» у сучасній літературі з'явилося відносно недавно, тому надати повне та змістовне поняття такому напрямку, як стратегічний облік на сьогодні достатньо важко. Це підтверджується дослідженнями вчених в галузі управлінського обліку:

- П.Й. Атамас вважає [9] що, управлінський облік - це облік, який зосереджується на зовнішніх факторах (таких як прибутковість конкурентів, частка на ринку тощо), тоді як для традиційного обліку характерна зосередженість на внутрішніх процесах i явищах;

- В.В. Панков, та В.Ф. Несвєтайлов [16] трактують управлінський облік як облік, спрямований на підтримку стратегічно орієнтованих рішень, тісно пов'язаний з ринково орієнтованою зовнішньою інформацією, яка має як фінансовий, так і не фінансовий характер, спрямований не тільки на фіксацію конкретних фактів, а більше на відстежування трендів, тенденцій або суттєвих змін, оперує плановими i прогнозними даними довгострокового характеру.

- В.3. Семанюк вважає [17], що управлінський облік - це підсистема обліку, функція стратегічного управління, яка забезпечує менеджерів інформацією про внутрішнє середовище діяльності підприємства для прийняття стратегічних рішень;

- В.В. Іванов та О.К. Хан [18] вважають що управлінський облік - це засіб інформаційної підтримки прийняття, реалізації й оцінювання стратегічних управлінських рішень і систематизованого збору й обробки показників, які характеризують стан не тільки внутрішньої фінансово-господарської діяльності, але й зовнішнього середовища (конкурентного, клієнтського тощо), яким керує організація;

- на думку К. Сімондса [19], управлінський облік - надання й аналіз даних щодо бізнесу і його конкурентів, які використовують для моніторингу та розвитку стратегії такого бізнесу.

- О.О. Довжик вважає [20], що управлінський облік є ефективним інструментом управління, тому що створює конкурентні переваги в ринковому середовищі, а саме, забезпечує підприємство ключовою інформацією, а досвід підприємств України свідчить, що практичне застосування управлінського обліку, на жаль, ще не набуло належного поширення, у зв'язку 3 невирішеним колом проблем. У сучасних умовах це питання вкрай актуальне й потребує свого дослідження.

Дослідження показує [1], що «П.Й. Атамас, В.В. Панков, В.Ф. Несвєтайлов, К.Уорд розглядають стратегічний управлінський облік як окремий його вид, на відміну від В.3. Семанюк, А.В. Шайкан - лише як підсистему обліку, а О.Б. Сулоєва, К.Є. Землякова, Б. Райн - як сам процес. Впровадження управлінського стратегічного обліку, як інструменту управління конкурентоспроможністю підприємств, розглядались зарубіжними вченими ще в 
ХХ сторіччі: К.Уорд відмічає необхідність відображення стратегічним управлінським обліком відносних фінансових результатів, яки досягнути бізнесом по відношенню 3 конкурентами, постачальниками та навіть 3 споживачами; на думку П.Й. Атамаса, стратегічний управлінський облік саме концентрується зовнішніх факторах, наприклад, частка ринку та прибутковість конкурентів; теоретичні та практичні аспекти впровадження стратегічного управлінського обліку на підприємствах та у фінансових установах в Україні були проведені й О.Г. Лищенко та Ю.А. Герасименко [1] (табл. 4).

Таблиця 1

Визначення сутності категорії «стратегічний управлінський облік»

\begin{tabular}{|c|c|}
\hline Автор & Визначення \\
\hline П.Й. Атамас & $\begin{array}{l}\text { Облік, який зосереджено на зовнішніх факторах (таких як прибутковість клієнтів, } \\
\text { частка ринку тощо), тоді як для традиційного обліку характерна зосередженість на } \\
\text { внутрішніх процесах та явищах. }\end{array}$ \\
\hline К. Уорд & Облік для стратегічного менеджменту. \\
\hline $\begin{array}{l}\text { В.В. Панков, } \\
\text { В.Ф.Несвєтайлов }\end{array}$ & $\begin{array}{l}\text { Облік, спрямований на підтримку стратегічно орієнтованих рішень, тісно пов'язаний } \\
\text { з ринковою орієнтованою зовнішньою інформацією, яка має як фінансовий так і не } \\
\text { фінансовий характер, спрямований не тільки на фіксацію конкретних трендів, тен- } \\
\text { денцій, а більше на відстеження трендів, тенденцій, або суттєвих змін, оперує пла- } \\
\text { новими і прогнозними даними довгострокового характеру. }\end{array}$ \\
\hline В.3. Семанюк & $\begin{array}{l}\text { Підсистема обліку, функція стратегічного управління, яка забезпечує менеджерам } \\
\text { інформацію про внутрішнє середовище діяльності підприємства для прийняття стра- } \\
\text { тегічних рішень. }\end{array}$ \\
\hline А.В. Шайкан & $\begin{array}{l}\text { Елемент теорії управління підприємством, облікової політики зокрема. Бухгалтерсь- } \\
\text { кий облік з метою стратегічного управління. }\end{array}$ \\
\hline $\begin{array}{l}\text { В.В. Іванов, } \\
\text { О.К. Хан }\end{array}$ & $\begin{array}{l}\text { Засіб інформаційної підтримки прийняття, реалізації й оцінювання стратегічних } \\
\text { управлінських рішень систематизованого збору й обробки показників, які характе- } \\
\text { ризують стан не тільки внутрішньої фінансово-господарської діяльності, але й зов- } \\
\text { нішнього середовища (конкурентного, клієнтського тощо), яким керує організація. }\end{array}$ \\
\hline К. Сімондз & $\begin{array}{l}\text { Надання й аналіз даних управлінського обліку щодо бізнесу і його конкурентів, яки } \\
\text { використовують для моніторингу та розвитку стратегії такого бізнесу. }\end{array}$ \\
\hline $\begin{array}{l}\text { С.Б. Сулоєва, } \\
\text { К.С. Землякова }\end{array}$ & $\begin{array}{l}\text { Процес надання інформації, яка спрямована на довгострокову перспективу, повинен } \\
\text { забезпечувати підтримку загальної конкурентоспроможної стратегії організації. }\end{array}$ \\
\hline $\begin{array}{l}\text { О.Г Лищенко, } \\
\text { Ю.А. Герасименко }\end{array}$ & $\begin{array}{l}\text { Це система стратегічного управління підприємством, яка здійснює інформаційну } \\
\text { підтримку процесу прийняття рішень шляхом збирання, реєстрації, аналізу, збері- } \\
\text { гання і передачі інформації про зовнішнє та внутрішнє середовище підприємства } 3 \\
\text { метою забезпечення його конкурентоспроможності. }\end{array}$ \\
\hline А. Пилипенко & $\begin{array}{l}\text { окремий вид обліку поряд з управлінським і фінансовим, що має на меті «відсте- } \\
\text { ження показників, необххдних для розробки стратегії підприємства». }\end{array}$ \\
\hline $\begin{array}{l}\text { Л.І. Проняєва, } \\
\text { К.Н. Галкіна }\end{array}$ & $\begin{array}{l}\text { Як елемент системи управління організацією регулює порядок збору, обробки й пе- } \\
\text { редачі планової, нормативної, прогнозної, облікової та іншої інформації за відповід- } \\
\text { ний період часу , яка використовується для цілей стратегічного аналізу . }\end{array}$ \\
\hline $\begin{array}{l}\text { М.А. Вахрушина, } \\
\text { М.I. Сидорова, } \\
\text { Л.І. Борисова }\end{array}$ & $\begin{array}{l}\text { Це одне з прогресивних інформаційних джерел, яке повинно забезпечити менедж- } \\
\text { мент організації інструментарієм для прийняття управлінських рішень, координу- } \\
\text { вання господарських функцій з метою досягнення ефективних результатів. Це облік, } \\
\text { який враховує зовнішні чинники макросередовища,орієнтований на облік невизна- } \\
\text { ченості, стратегію управління ризиком. }\end{array}$ \\
\hline
\end{tabular}

* Складено на підставі аналізу джерел $[1,18]$

Проведено дослідження розвитку управлінського обліку в Україні дозволило структурувати етапи відповідно до історичного та практичного аспекту:

-1 етап - середина XIX ст. - кінець XIX ст: облік починають розглядати як функцію управління. Почали визначатися такі показники, як вартість часу обробки сировини, собівартість одиниці продукції, витрати на одного робітника.;

- 2 етап - початок ХХ ст. - середина 50-х років XX ст.: в періоді характерним $є$ загострення конкуренції, ускладнення технології й організації виробництва. Відбувається виділення управлінського облі- ку як окремої системи і паралельне функціонування двох бухгалтерій (фінансової та управлінської);

- 3 етап - 50-ті - початок 80-х pp. XX ст.: розвиток транснаціональних корпорацій, відбувається впровадження директкостингу. Розробка Спенсером А. Такером методу «тариф - година - машина», що посилювало контроль за кожним технологічним процесом в межах виробничого центру відповідальності;

- 4 етап - середина 80-х pp. - кінець ХХ ст.: автоматизація виробництва, комп'ютерні інформаційні технології, глобальна конкуренція. Управлінський облік набуває стратегічного характеру; 
- 5 етап: початок XXI ст. - теперішній час: вплив зовнішніх факторів на діяльність підприємства $\epsilon$ домінуючими над внутрішніми. У зв'язку з загостренням конкуренції на внутрішніх ринках під впливом глобалізації процесів що потребує саме стратегічного управлінського обліку на підприємстві з метою забезпечення конкурентоспроможності та діяльності.

Висновки та перспективи подальших досліджень. Проведено дослідження дозволяє зробити наступні висновки:

- дослідження підтвердило багато підходів щодо формування етапів розвитку управлінського обліку, але деякі автори поставили під сумнів існування в Україні управлінського обліку, з чим не можна погодитись;

- результатом дослідження є формування власного підходу в історичному та практичному аспекті розвитку управлінського обліку та підтвердження існування та застосування сучасного напряму управлінського обліку - стратегічного управлінського обліку у зв'язку з тим, що в умовах господарювання підприємств в сучасних ринкових умовах зовнішні фактори є домінуючими над внутрішніми;

- для ефективного розвитку вітчизняних підприємств, забезпечення ефективності їх діяльності та конкурентоспроможності в сучасних умовах необхідна адаптація зарубіжного досвіду організації та веденні стратегічного управлінського обліку к національним економічним та ринковим умовам, врахування специфіки традицій у виробництві та споживанні товарів, діяльності промислових підприємств в Україні тощо [1].

\section{Література}

1. Купріна Н.М. Стратегічний управлінський облік як інструмент забезпечення конкурентоспроможності та ефективності діяльності підприємства [Електронний ресурс] / Н.М. Купріна // Економіка харчової промисловості. - 2017. Т. 9. - № 3. - 45 - 51 с. - Режим доступу: http://oaji.net/articles/2017/3396-1508483380.pdf;

2. Васюта-Беркут О.І. Теорія бухгалтерського обліку: [навч. посіб.] / О.І. Васюта-Беркут, Г.Ф. Шепітько, Н.О. Ромашевська ; за заг. ред. В.Б. Захожая. - К.: МАУП,2001. - 179 с.

3. Корецький М.Х. Управлінський облік: [навч. посіб.] / М.Х. Корецький, Н.В. Дацій, Л.В. Пельтек. К.: центр учбової літератури, 2007 - 296 с.

4. Бабарикін С.В. Виникнення і розвиток теорії обліку витрат у США та Великобританії / С.В. Бабарикін // Бухгалтерський облік. - 1997. - № 3. - С. 91-94.

5. Соколов Я.В. Бухгалтерський облік: від витоків до наших днів: [навч. посібник] / Я.В. Соколов. - М $\therefore$ Аудит, ЮНИТИ, 1996. - 638 с.

6. Гарасим П.М. Курс управлінського обліку: [навч. посіб.] / П.М. Гарасим, Г.П. Журавель, П.Я. Хомин. - К.: Знання, $2007-314$ с.

7. Добровський В.М. Управлінський облік: [навч. - метод, посіб. для самост. вивч. дисц.] / В. М. Добровський, Л.В. Гнилицька, Р.С. Коршикова ; за ред. В. М. Добровського. - К.: КНЕУ, 2003. - 235 с.

8. Nelson M. The origin and evolution of management accounting: a review of the theoretical framework/ Nelson Maina Waweru // Problemsand Perspectivesin Management. - 2010. - Volume 8, Issue 3. - S.165-182. - Retrieved from: http://businessperspectives.org/journals_free/ppm /2010/PPM_EN_.

9. Атамас П.Й. Управлінський облік : [навч. посіб.] / П.Й. Атамас. - Київ: Центр навчальної літератури, 2006. $-440 \mathrm{c.}$

10. Королович О. Управлінський облік в Україні та питання становлення його на промислових підприємствах [Електронний ресурс] / О. Королович // Економічний аналіз. - 2012. - № 11(4). - Режим доступу: http://dspace.msu. edu.ua:8080/bitstream/123456789/930/1/Королович\%20О.\%20О\%20\%287\%29.pd.

11. Акольська О.В. Управлінський облік проблеми його функціонування в сучасних умовах управління підприємством [Електронний ресурс] / О.В. Акольська, О.В. Білоцерківський // Економіка та управління підприємствами машинобудівної галузі: проблеми теорії та практики. - 2009. - № 3(7). - Режим доступу: https://www.khai.edu/csp/nauchportal/Arhiv/EUPMG/2009/.

12. Крушельницька Т.А. Управлінський облік та його складові [Електронний ресурс] / Т.А. Крушельницька, Г.Є. Павлова // Економіка АПК. - 2009 . - № $20 . \quad$ - Режим доступу: http://www.agrosvit.info/pdf/20_2009/6.pdf

13. Костенко О.М. Управлінський облік - інформаційна система прийняття рішень [Електронний ресурс] / О.М. Костенко // Агросвіт. - 2013. - № 1. - Режим доступу: http://www.agrosvit.info/pdf/1 2013/2.pdf

14. Нападовська Л.В. Управлінський облік: [підруч. для студентів вищих навч. закладів] / Л.В. Нападовська. - К. : Книга, 2004. - 544 с.

15. Лищенко О.Г. Стратегічний управлінський облік як ефективний інструмент управління конкурентоспроможністю [Електронний ресурс] / О.Г. Лищенко, Ю.А. Герасименко // Економіка та підприємництво. 2016. - № 1(87). - Режим доступу: $\underline{\text { http://eir.zntu.edu.ua/bitstream/123456789/1515/1/ }}$ Lishchenko_Strategic\%20management\%20accounting.pdf.

16. Панков В.В. Базові принципи і допущення стратегічного управлінського обліку / В.В. Панков, В.Ф. Несветайло // Міжнародний бухгалтерський облік. - 2012. - № 7. - С. 2 - 7. 
17. Семанюк В.3. Формування підсистеми стратегічного обліку в умовах ринкових відносин / В.3. Семанюк // Формування ринкових відносин в Україні : зб. наук. праць. - 2010. - Вип. 11(114). - С. 59-64.

18. Ivanov V.V. Upravlencheskij uchet dlja jeffektivnogo menedzhmenta / V.V. Ivanov, O.K. Han. - M.: INFRA-M, 2009. - 208 p.

19. SimmondsK. The accounting assessment of competitive position / K. Simmonds // European Journal of Marketing, Organization and Society. - 1986. - № 12(4). - P. 357-374.

20. Довжик О.О. Роль управлінського обліку та проблеми його впровадження на підприємствах [Електронний ресурс] /О.О.Довжик // Вісник. - 2012. - № 2. - Режим доступу: http://dev.pdaa.edu.ua/sites/default/files/visnyk /2012/ 02/174.pdf.

Стаття надійшла 11.02.2018

Стаття прийнята до друку 25.02.2018

Доступно в мережі Internet 31.03.2018

\author{
Куприна Н.М. \\ кандидат экономических наук, доцент \\ кафедра учёта и аудита \\ E-mail: k.natali@ukr.net
}

Рудюк И.

Студент 4 курса фракультета экономики, бизнеса и контроля

Одесская национальная академия пищевых технологий

ул. Канатная, 112, г. Одесса, Украина, 65039

E-mail: ruduk2012@gmail.com

\title{
РАЗВИТИЕ УПРАВЛЕНЧЕСКОГО УЧЕТА: ИСТОРИЧЕСКИЙ И ПРАКТИЧЕСКИЙ АСПЕКТ
}

Целью исследования является анализ научных работ о развитии управленческого учета, подходов к определению сущности категорий «управленческий учет», «стратегических управленческий учет». Проведенное исследование подходов к этапам развития управленческого учета в историческом и практическом аспекте позволило их обобщение и структурирование, а также выделение стратегического управленческого учета, как современного вида учета для эффективной деятельности предприятий и обеспечения их конкурентоспособности.

В процессе исследования использовались методы: системного сравнительного анализа и синтеза (для анализа подходов к классификации этапов развития управленческого учета); методы теоретического обобщения (для исследования и выделения понятийного аппарата категорий »).

Проведенные исследования подтвердили, что первое упоминание о возникновении управленческого учета датируется 1855 г. в США и его формирование начинается с первых попыток унификации учетных процедур. С начала 1990-х гг. В экономически развитых странах получают разработку новые методы управленческого учета: общая система управления затратами, учет затрат по видам деятельности, калькулирования по операциям, система сбалансированных показателей и т.д. Исследование подтвердило, множество подходов к формированию этапов развития управленческого учета, но некоторые авторы поставили под сомнение существование управленческого учета в Украине, с чем нельзя согласиться. Результатом исследования является формирование подхода в историческом и практическом аспекте развития управленческого учета и подтверждения существования, а так же применения современного направления управленческого учета - стратегического управленческого учета в связи с тем, что в условиях деятельности предприятий в современных рыночных условиях внешние факторы являются доминирующими над внутренними.

Заключается в создании подхода к формированию этапов развития управленческого учета в историческом и практическом аспектах за период с середины XIX в. - начало XXI в., а также необходимость исследования категорий «управленческий учет», «стратегических управленческий учет» для дальнейших научных исследования.

Полученные результаты направлены на формирование методов управленческого учета в современных условиях хозяйствования предприятий для повышения эффективности их деятельности и конкурентоспособности.

Ключевые слова: управленческий учет, стратегических управленческий учет, этапы развития, предприятие, внешние факторы, конкурентоспособность. 


\author{
Kuprina N. \\ Ph.D., Associate Professor \\ Department of Accounting and Auditing \\ E-mail: k.natali @ukr.net \\ Rudiuk I. \\ The student of the fourth grade of Economy, Business and Control Faculty \\ Odessa National Academy of Food Technologies \\ Kanatna str., 112, Odesa, Ukraine, 65039 \\ E-mail: ruduk2012@gmail.com
}

\title{
DEVELOPMENT OF MANAGERIAL ACCOUNTING: HISTORICAL AND PRACTICAL ASPECT
}

The purpose of the research is to analyze scientific works on the development of managerial accounting, approaches to the definition of essence of the categories "managerial accounting", "strategic managerial accounting". The research of approaches to the development stages of managerial accounting in historical and practical aspects allowed to carry out their generalization, as well as substantiation of definition of strategic managerial accounting as modern form of accounting for effective activity of enterprises and ensuring their competitiveness.

During the process of the research, the following methods were used: system comparative analysis and synthesis (for the analysis of approaches to the classification of development stages of managerial accounting); methods of theoretical generalization (for research and definition of conceptual apparatus of categories).

The research confirmed that the first mention of the emergence of managerial accounting dates back to 1855 in the United States, and its formation begins with the first attempts to unify accounting procedures. Since the beginning of the 1990s, new methods of managerial accounting have been developed in economically developed countries: general cost management system, cost accounting by type of activity, calculation by transactions, system of balanced indicators, etc. The research has confirmed many approaches to the formation of development stages of managerial accounting, but some authors have questioned the existence of managerial accounting in Ukraine, which can not be agreed. The result of the research is formation of the own approach in historical and practical aspect of the development of managerial accounting and confirmation of existence and application of modern direction of managerial accounting - strategic managerial accounting in connection with the fact that under the conditions of enterprise management in the current market conditions external factors are dominant over the internal.

It is necessary to create the approach to the formation of development stages of managerial accounting in historical and practical aspects from the middle of the XIX century to the beginning of XXI century, as well as to investigate the categories of "managerial accounting", "strategic managerial accounting" for further scientific research.

The obtained results are aimed at the formation of managerial accounting methods in the current conditions of enterprise management in order to ensure their efficiency and competitiveness.

Key words: managerial accounting, strategic managerial accounting, development stages, enterprise, external factors, competitiveness.

\section{References}

1. Kuprina, N. M. (2017). Stratehichnyi upravlinskyi oblik yak instrument zabezpechennia konkurentospromozhnosti ta efektyvnosti diialnosti pidpryiemstva. Ekonomika Kharchovoi Promyslovosti, 9(3), 45-51. Retrieved from http://oaji.net/articles/2017/3396-1508483380.pdf

2. Vasiuta-Berkut, O. I., Shepitko, H. F., \& Romashevska, N. O. (2001). Teoriia bukhhalterskoho obliku (V. B. Zakhozhaia, Ed.). K.: MAUP.

3. Koretskyi, M. Kh., Datsii, N. V., \& Peltek, L. V. (2007). Upravlinskyi oblik. K.: Tsentr uchbovoi literatury.

4. Babarykin, S. V. (1997). Vynyknennia i rozvytok teorii obliku vytrat u SShA ta Velykobrytanii. Bukhhalterskyi Oblik, (3), 91-94.

5. Sokolov, Ya. V. (1996). Bukhhalterskyi oblik: Vid vytokiv do nashykh dniv. M.: Audyt, YuNYTY.

6. Harasym, P. M., Zhuravel, H. P., \& Khomyn, P. Ya. (2007). Kurs upravlinskoho obliku. K.: Znannia.

7. Dobrovskyi, V. M., Hnylytska, L. V., \& Korshykova, R. S. (2003). Upravlinskyi oblik (V. M. Dobrovskoho, Ed.). K.: KNEU. 
8. Nelson, M. W. (2010). The origin and evolution of management accounting: A review of the theoretical framework. Problemsand Perspectivesin Management, 8(3), 165-182. Retrieved from http://businessperspectives.org/journals_free/ppm /2010/PPM_EN_.

9. Atamas, P. Y. (2006). Upravlinskyi oblik. Kyiv: Tsentr navchalnoi literatury.

10. Korolovych, O. (2012). Upravlinskyi oblik v Ukraini ta pytannia stanovlennia yoho na promyslovykh pidpryiemstvakh. Ekonomichnyi Analiz, (11 $\quad$ (4)). Retrieved from http://dspace.msu.edu.ua:8080/bitstream/123456789/930/1/Королович\%200.\%200\%20\%287\%29.pd.

11. Akolska, O. V., \& Bilotserkivskyi, O. V. (2009). Upravlinskyi oblik problemy yoho funktsionuvannia v suchasnykh umovakh upravlinnia pidpryiemstvom. Ekonomika Ta Upravlinnia Pidpryiemstvamy Mashynobudivnoi

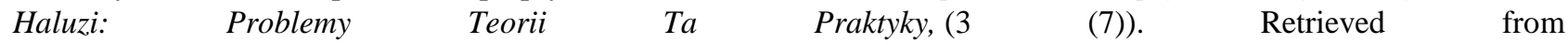
https://www.khai.edu/csp/nauchportal/Arhiv/EUPMG/2009/.

12. Krushelnytska, T. A., \& Pavlova, H. Ye. (2009). Upravlinskyi oblik ta yoho skladovi. Ekonomika $A P K$, (20). Retrieved from http://www.agrosvit.info/pdf/20_2009/6.pdf

13. Kostenko, O. M. (2013). Upravlinskyi oblik - informatsiina systema pryiniattia rishen. Ahrosvit, (1). Retrieved from http://www.agrosvit.info/pdf/1_2013/2.pdf

14. Napadovska, L. V. (2004). Upravlinskyi oblik. K.: Knyha.

15. Lyshchenko, O. H., \& Herasymenko, Yu. A. (2016). Stratehichnyi upravlinskyi oblik yak efektyvnyi instrument upravlinnia konkurentospromozhnistiu. Ekonomika Ta Pidpryiemnytstvo, (1 (87)). Retrieved from http://eir.zntu.edu.ua/bitstream/123456789/1515/1/ Lishchenko_Strategic management accounting.pdf.

16. Pankov, V. V., \& Nesvetailo, V. F. (2012). Bazovi pryntsypy i dopushchennia stratehichnoho upravlinskoho obliku. Mizhnarodnyi Bukhhalterskyi Oblik, (7), 2-7.

17. Semaniuk, V. Z. (2010). Formuvannia pidsystemy stratehichnoho obliku v umovakh rynkovykh vidnosyn. Formuvannia Rynkovykh Vidnosyn v Ukraini, (11 (114)), 59-64.

18. Ivanov, V. V., \& Han, O. K. (2009). Upravlencheskij uchet dlja jeffektivnogo menedzhmenta. M.: INFRAM.

19. Simmonds, K. (1986). The accounting assessment of competitive position. European Journal of Marketing, Organization and Society, (12 (4)), 357-374.

20. Dovzhyk, O. O. (2012). Rol upravlinskoho obliku ta problemy yoho vprovadzhennia na pidpryiemstvakh. Visnyk, (2). Retrieved from http://dev.pdaa.edu.ua/sites/default/files/visnyk /2012/ 02/174.pdf.

Received 11 February 2018

Approved 25 February 2018

Available in Internet 31.03.2018 